(C) 2018 International Journal of Nursing and Midwifery Science (IJNMS)

This is an Open Access article distributed under the terms of the Creative Commons Attribution 4.0 International License which permits unrestricted non-commercial use, distribution, and reproduction in any medium, provided the original work is properly cited.

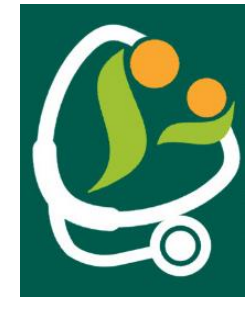

\title{
POTENCY WATER STEW OF AVERRHOA BILIMBI L FOR ANTIHYPERTENSIVE
}

Indah Lestari $^{1}$, Anissa Melania ${ }^{2}$, Budi Prasetyo ${ }^{3}$

STIKes Bina Sehat PPNI Mojokerto ${ }^{1}$, Stikes IST Buton ${ }^{2}$

\section{ABSTRACT}

Hypertension is often referred to as a "silent killer" because patients often do not feel any significant symptoms. Uncontrolled hypertension has an increased risk of severe health problems, but the patient is less concerned about taking the drug regularly. AVERRHOA BILIMBI L contains about $6 \mathrm{mg} / \mathrm{kg}$ total of volatile compounds also oxalate compounds; oils evaporated, phenol, flavonoid, and pectin, amino acids, citric acid, phenolics, potassium ions. It plays a role in decreasing blood pressure. The research objective proved the effectiveness of AVERRHOA BILIMBI L against changes in hypertensive blood pressure. The research design was pre-experiment one group pre-posttest approach. The population was all of the hypertension patient in Sumber Girang Village and Karang Tengah Village as many as 80 people. The Sample was hypertension patient who fulfills criteria of 60 people, with purposive sampling. The independent variable was the provision of AVERRHOA BILIMBI L water stew and the dependent variable was the hypertension blood pressure change. The results showed significant changes in blood pressure, in which most respondents showed systole and diastolic results, in the category of mild hypertension (67\% of respondents) and moderate (47\% of respondents). The result of paired sample T-test statistic showed significant $=0.000$, so water stew of AVERRHOA BILIMBI L effectively against the decrease of hypertension blood pressure. Potassium plays a role in enlarging the size of endothelial cells and increasing the production of nitric oxide that will trigger dilation reactions and vascular reactivation that will lower blood pressure.

AVERRHOA

BILIMBI L,

Blood

Pressure,

Hypertension. 


\section{INTRODUCTION}

Hypertension is currently one of the leading causes of death and the risk of further complications. Symptoms of hypertension often occur when hypertension is advanced where blood pressure reaches a certain meaningful number. Complications such as stroke, ischemia, kidney disorders become a scourge for society (Triyanto, 2014).

Constraints often faced in pharmacological treatment are a lot of patients with hypertension who not disciplined in taking blood pressurelowering drugs.Also, side effects of medicines caused by a fear for the patient. For these reasons, hypertensive patients look for other economic and minimal side effects of treatment, through natural remedies using natural ingredients such as fruits, vegetables, and herbs (Muhammadun, 2010)

WHO 2016 at least 839 million cases of hypertension estimates to be 1.1 billion by 2025 or about $29 \%$ of the total population of the world. Where the sufferer is more in women $(30 \%)$ than men $(29 \%)$. Approximately $80 \%$ rise in cases of hypertension occurs mainly in developing countries (Badan Penelitian dan Pengembangan Kesehatan, 2013)

Herbal treatment selection becomes an alternative for people in Indonesia. One of the plants has a lot of positive content is AVERRHOA BILIMBI L. Some people consumed AVERRHOA BILIMBI $L$ feel symptoms of hypertension reduced, including a decrease in blood pressure. AVERRHOA BILIMBI L contains about $6 \mathrm{mg} / \mathrm{kg}$ total of volatile compounds and a group of oxalate compounds; oils evaporated, phenol, flavonoid, and pectin, also, there are also amino acids, citric acid, phenolics, potassium ions, sugars and vitamins and minerals, and consists of fibers. Besides, it also contains several substances that affected blood pressure such as potassium and flavonoids (Lim, 2003). Potassium is a nutrient that plays a role in decreasing blood pressure. Potassium plays a role in enlarging the size of endothelial cells and increase the production of nitric oxide that will trigger a reaction dilatation and vascular reactivation that will lower blood pressure (Safitri R, 2015).

Controlling blood pressure in hypertensive patients is very important. We always have to remember that when blood pressure continues high, then the heart muscle will thicken (hypertrophy) and cause its function as the pump becomes disturbed, then the heart will experience dilatation and contraction ability is reduced. (Muhammadun, 2010). If in pharmacological treatment can be reduced by giving starfruit. It didn't only improve blood pressure, But it will also work on our kidneys and liver. The fruit is interested in researchers to prove the effectiveness of Averrhoa Bilimbi L on changes in blood pressure hypertension.

\section{MATERIALS AND METHODS}

The research design used in this study was pre-experimental with QueasyExperiment design - Nonequivalent with the control group. The population of this study was all patients with hypertension in the village of Karang Tengah and Sumber Girang as many as 80 people. Sampling technique in this research used purposive sampling. A sample of the 
study were some of the hypertension sufferers in Karang Tengah and Sumber Girang village about 60 people, which fulfilled the research criteria: age 50-65 years, mild and moderate degree hypertension, no dependence on drugs, no smoking, no obesity, and no complication. The procedure of making the water stew of AVERRHOA BILIMBI L by the fruit used is a green fruit with average size per fruit of 10 grams of 3 pieces, fruit cut into pieces and then put into a saucepan with 3 cups water, boil 10 minutes until remaining 1 cup or $100 \mathrm{ml}$. Then added 1 tablespoon (13 gr) of low-calorie sugar "T" per 100 $\mathrm{ml}$. After that in the cold then filtered and drunk after breakfast. Provision of water stew for seven consecutive days. Compliance and time- consuming Averrhoa Bilimbi L monitored by using the checklist form.

The blood pressure was measured using a sphygmomanometer digital. Blood pressure is checked as the subjects sit quietly for 5 minutes at break time. Confounding variables are physical activity, fat intake, fiber, vitamin $\mathrm{C}$, sodium, potassium, and calcium. Physical activity data were obtained through interviews using the International Physical Activity Questionnaire (IPAQ) questionnaire. Physical activity reported by the subjects includes activities that have only been done during the last seven days. Physical activity scores are calculated in accordance with the IPAQ scoring protocol and expressed in units of METminutes/week. The categories of physical activity levels in the frequency distribution tables adopted from IPAQ, ie mild (<600 MET- minute/week), moderate (600-2999 MET- minutes/week), and weight $(\geq 3000$ MET-minutes/week). Data on fat, fiber, vitamin $\mathrm{C}$, sodium, potassium, and calcium intake were obtained by recall with the 6x24 hour Food Recall form. Recall results in unit of household size (URT) are converted into gram units, then analyzed with Nutrisurvey 2007. Individual needs are obtained by converting Numbers of Nutritional Adequacy (AKG) for individuals by comparing actual body weight with reference weight in 2013 AKG table, then multiplied $100 \%$ hence got a percentage of sufficiency level of nutrient intake. The level of sufficiency of macro and fiber nutrients is divided into 5 categories, the heavy deficit ( $<70 \%$ AKG), the moderate deficit (70$79 \%$ AKG), the mild deficit (80-89\% AKG), enough (90-119\% AKG), and more $(\geq 120 \% \quad$ AKG $)$. While micronutrients are divided into 2 , less if $<77$ percent of $A K G$ and enough if $\geq 77$ percent $\mathrm{AKG}$.

The data obtained were analyzed statistically. Characteristics of the subject were analyzed using descriptive analysis. To test the normality of data using the Shapiro-Wilk test. Differences in systolic blood pressure before and after intervention using the Wilcoxon test. To test the association between fiber intake, sodium intake, potassium intake and calcium intake with systolic blood pressure after intervention using Pearson test and using Rank Spearman test to examine the relationship between fat intake, vitamin $\mathrm{C}$ intake, and physical activity with systolic blood pressure after an intervention. Comparison of blood pressure measurement data before and after supplementation of water stew in control and experimental group was 
analyzed by the T-paired test. Multivariate analysis used linear regression analysis.

\section{RESULTS}

The characteristics of those respondents are presented in a chart of frequency distribution and percentage as the followings:

Table 1 Distribution of respondents by age, gender, genetics, and IMT in the control group and experimental group at Sumber Girang and Karang Tengah, Mojokerto

\begin{tabular}{|c|c|c|c|c|c|}
\hline \multirow[t]{2}{*}{$\begin{array}{l}\mathrm{N} \\
\mathrm{O}\end{array}$} & \multirow[t]{2}{*}{$\begin{array}{l}\text { VARIA } \\
\text { BLE }\end{array}$} & \multicolumn{2}{|c|}{ Control group } & \multicolumn{2}{|c|}{$\begin{array}{l}\text { Experimental } \\
\text { group }\end{array}$} \\
\hline & & $\begin{array}{l}\text { Freque } \\
\text { ncy }\end{array}$ & $\begin{array}{l}\text { Percent } \\
\text { age }\end{array}$ & $\begin{array}{l}\text { Freque } \\
\text { ncy }\end{array}$ & $\begin{array}{l}\text { Percent } \\
\text { age }\end{array}$ \\
\hline \multirow[t]{7}{*}{1.} & Age & & & & \\
\hline & $41-45$ & 5 & $17 \%$ & 3 & $10 \%$ \\
\hline & $46-50$ & 4 & $13 \%$ & 6 & $20 \%$ \\
\hline & $51-55$ & 9 & $30 \%$ & 10 & $33 \%$ \\
\hline & $56-60$ & 7 & $23 \%$ & 6 & $20 \%$ \\
\hline & $61-65$ & 5 & $17 \%$ & 5 & $17 \%$ \\
\hline & TOTAL & 30 & $100 \%$ & 30 & $100 \%$ \\
\hline \multirow[t]{4}{*}{2.} & Gender & & & & \\
\hline & Male & 11 & $37 \%$ & 8 & $27 \%$ \\
\hline & Female & 19 & $63 \%$ & 22 & $73 \%$ \\
\hline & TOTAL & 30 & $100 \%$ & 30 & $100 \%$ \\
\hline \multirow[t]{4}{*}{3.} & $\begin{array}{l}\text { Genetic } \\
\mathrm{s}\end{array}$ & & & & \\
\hline & Yes & 10 & $33 \%$ & 12 & $40 \%$ \\
\hline & No & 20 & $67 \%$ & 18 & $60 \%$ \\
\hline & TOTAL & 30 & $100 \%$ & 30 & $100 \%$ \\
\hline \multirow[t]{7}{*}{4.} & IMT & & & & \\
\hline & $\begin{array}{l}\text { Thin } \\
\text { skinny } \\
\text { level }\end{array}$ & 8 & $27 \%$ & 8 & $27 \%$ \\
\hline & $\begin{array}{l}\text { Thin } \\
\text { weight }\end{array}$ & 0 & $0 \%$ & 0 & $0 \%$ \\
\hline & Normal & 16 & $53 \%$ & 20 & $66 \%$ \\
\hline & $\begin{array}{l}\text { Light } \\
\text { weight } \\
\text { level }\end{array}$ & 6 & $20 \%$ & 2 & $7 \%$ \\
\hline & $\begin{array}{l}\text { Fat } \\
\text { weight } \\
\text { level }\end{array}$ & 0 & $0 \%$ & 0 & $0 \%$ \\
\hline & TOTAL & 30 & $100 \%$ & 30 & $100 \%$ \\
\hline
\end{tabular}

The result of this research suggested that the average of respondent's age is 51-55 years old and most respondents were women $(70 \%)$. This result is an incidence of hypertension, as age increases. Based on the table it was suggested that the majority of both experimental and control group comparable, both with a genetic history and no genetic history.

Tabel 2. Description of food intake during the intervention in the experimental group

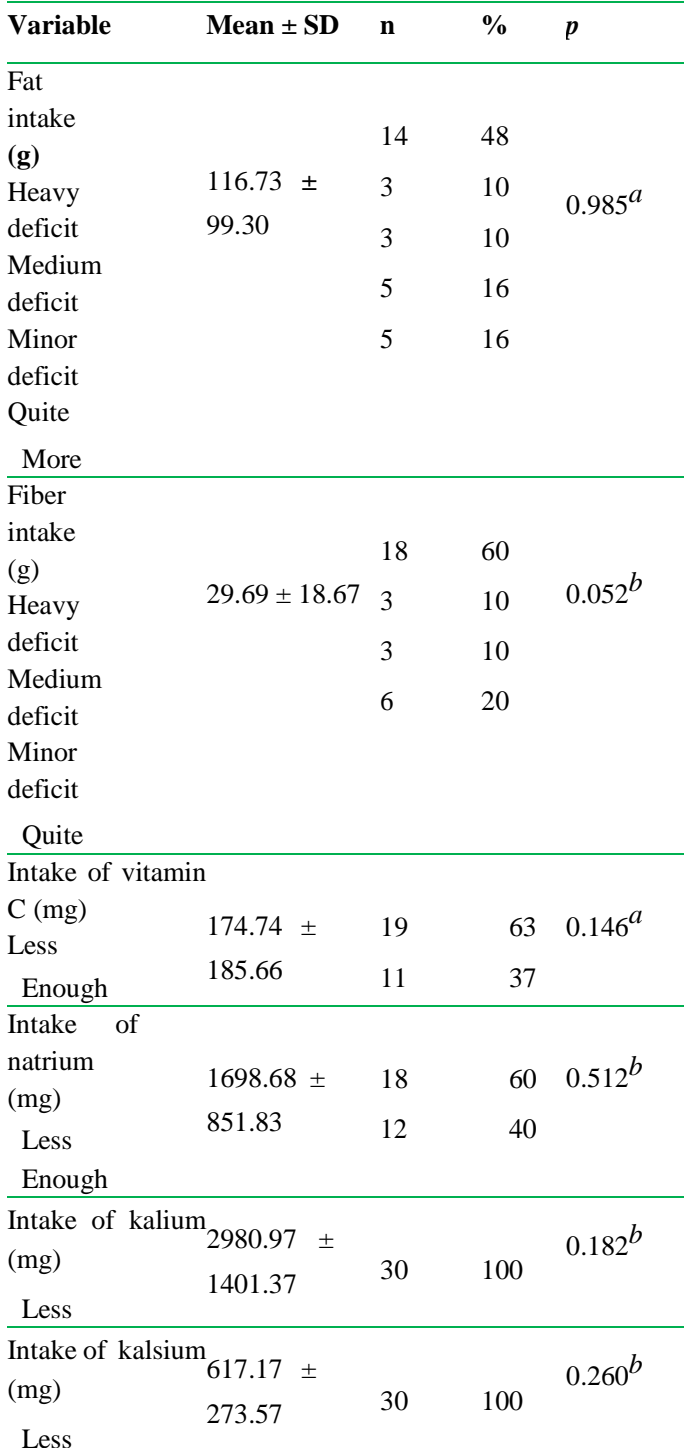

$a$ Test correlation Rank Spearman

$b$ Test correlation Pearson

Table 2, it can be seen that all the variable intake had no significant relationship ( $p>$ 0.05) so that it can be concluded that confounding variables had no effect on systolic blood pressure reduction 
Table 3 Distribution of Blood Pressure of Hypertension sufferer before and after being given water stew of AVERRHOA BILIMBI $L$, the control group and the experimental group in Sumber Girang and Karang Tengah Mojokerto District

\begin{tabular}{|c|c|c|c|c|c|c|c|c|}
\hline \multirow{3}{*}{$\begin{array}{l}\text { Criteria } \\
\mathrm{mmHg}\end{array}$} & \multicolumn{4}{|c|}{ Control Group } & \multicolumn{4}{|c|}{ Experimental group } \\
\hline & \multicolumn{2}{|c|}{ Pre } & \multicolumn{2}{|c|}{ Post } & \multicolumn{2}{|c|}{ Pre } & \multicolumn{2}{|c|}{ Post } \\
\hline & $\mathrm{f}$ & $\%$ & $\mathrm{~F}$ & $\%$ & $\mathrm{~F}$ & $\%$ & $\mathrm{~F}$ & $\%$ \\
\hline $\begin{array}{l}\text { Normal } \\
(<130 /<8 \\
5 \mathrm{mmHg})\end{array}$ & 0 & 0 & 1 & $3 \%$ & 0 & 0 & 3 & $\begin{array}{l}10 \\
\%\end{array}$ \\
\hline $\begin{array}{l}\text { Pre } \\
\text { Hyperten } \\
\text { sion } \\
(<130 \text { - } \\
139 /<85- \\
89)\end{array}$ & 7 & $\begin{array}{l}23 \\
\%\end{array}$ & 6 & $\begin{array}{l}20 \\
\%\end{array}$ & 4 & $\begin{array}{l}13 \\
\%\end{array}$ & 5 & $\begin{array}{l}17 \\
\%\end{array}$ \\
\hline $\begin{array}{l}\text { Mild } \\
\text { Hyperten } \\
\text { sion } \\
(140- \\
159 / 90- \\
99)\end{array}$ & 9 & $\begin{array}{l}30 \\
\%\end{array}$ & $\begin{array}{l}1 \\
0\end{array}$ & $\begin{array}{l}34 \\
\%\end{array}$ & 6 & $\begin{array}{l}20 \\
\%\end{array}$ & $\begin{array}{l}1 \\
4\end{array}$ & $\begin{array}{l}47 \\
\%\end{array}$ \\
\hline Medium & 1 & 47 & 1 & 40 & 2 & 67 & 8 & 26 \\
\hline $\begin{array}{l}\text { Hyperten } \\
\text { sion } \\
(160- \\
179 / 100- \\
109)\end{array}$ & 4 & $\%$ & 2 & $\%$ & 0 & $\%$ & & $\%$ \\
\hline $\begin{array}{l}\text { Weight } \\
\text { Hyperten } \\
\text { sion } \\
(180- \\
209 / 110- \\
119)\end{array}$ & 0 & $0 \%$ & 1 & $3 \%$ & 0 & $0 \%$ & 0 & 0 \\
\hline TOTAL & $\begin{array}{l}3 \\
0\end{array}$ & $\begin{array}{l}10 \\
0 \%\end{array}$ & $\begin{array}{l}3 \\
0\end{array}$ & $\begin{array}{l}10 \\
0 \%\end{array}$ & $\begin{array}{l}3 \\
0\end{array}$ & $\begin{array}{l}10 \\
0 \%\end{array}$ & $\begin{array}{l}3 \\
0\end{array}$ & $\begin{array}{l}10 \\
0 \%\end{array}$ \\
\hline
\end{tabular}

The results showed, in the experimental group experienced significant changes, from the condition of moderate hypertension $(67 \%)$ toward an increase in the number of respondents with mild hypertension (47\%). Compared to the control group it was found that although there was a decrease in the number of respondents in moderate $(47 \%$ to $40 \%$ ) and mild (30\% to $34 \%$ ) hypertension, the number of decreases was not as significant as the experimental group.

Table 4. Mean blood pressure before and after giving of water stew of AVERRHOA BILIMBI $L$ in the experimental group

\begin{tabular}{|c|c|c|c|}
\hline $\begin{array}{l}\text { Systolic Blood } \\
\text { Pressure } \\
\text { (Before) (mmHg } \\
\pm \text { SD) }\end{array}$ & $\begin{array}{l}\text { Systolic Blood } \\
\text { Pressure (After) } \\
(\mathrm{mmHg} \pm \mathrm{SD})\end{array}$ & $\begin{array}{l}\Delta \\
(\mathrm{mmHg} \\
\pm \mathrm{SD})\end{array}$ & $\mathrm{P}$ \\
\hline $163.57 \pm 9.70$ & $145.05 \pm 7.37$ & $\begin{array}{l}-18.52 \\
5.68\end{array}$ & $\pm 0.000^{a}$ \\
\hline
\end{tabular}

${ }^{a}$ Test Different Wilcoxon

Different test results in table 4 showed a significant decrease in systolic blood pressure $(\mathrm{p}=0.000)$ before and after star fruit juice extract of $18.52 \pm 5.68 \mathrm{mmHg}$ means that water stew of AVERRHOA BILIMBI L can lower blood pressure significantly.

\section{DISCUSSION}

Starfruit contains about $6 \mathrm{mg} / \mathrm{kg}$ total volatile compounds and includes the compound oxalate, oils evaporate, phenols, flavonoids, and pectin, as it also included amino acids, citric acid, phenol, potassium ions, sugars and vitamins and minerals, and is composed of fiber. Based on a study, test results of Averrhoa Bilimbi L content Averrhoa Bilimbi L $100 \mathrm{ml}$ contains $32.6 \mathrm{mg}$ vitamin $\mathrm{C}, 0.07 \%$ potassium and $41 \mathrm{mg}$ flavonoids (Hasim, 2014).

Potassium is a nutrient that plays a role in decreasing blood pressure. Potassium plays a role in enlarging the size of endothelial cells and increasing the production of nitric oxide that will trigger dilation reactions and vascular reactivation that will lower blood pressure (Adrogué HJ \& NE, 2007). Potassium inhibits the action of the renin-angiotensin system, by inhibiting renin secretion because the secretion of 
renin is inversely proportional to elevated levels of potassium ions in the plasma. Renin that should turn angiotensinogen into angiotensin I then become angiotensin II which is a potent vasoconstrictor. However, because of the block in this system, the blood vessels will experience vasodilatation so that blood pressure will drop. Potassium also lowers the secretion of aldosterone which can lead to decreased retention of sodium and water by the kidney, so that blood pressure falls. Also, high potassium concentration in the intracellular fluid can relax the smooth muscle cells of the blood vessels; they can reduce the resistance of peripheral blood vessels that can lower blood pressure (Tashakori-sabzevar et al., 2016).

While flavonoids affect the work of angiotensin-converting enzyme (ACE), which it will inhibit angiotensin one conversion into angiotensin II. It leads to reduced secretion of aldosterone so be natriuresis (inhibit sodium and water retention in the kidney tubules), inhibits sympathetic nerve stimulation to become vasodilation, inhibits the secretion of endogenous endothelin. So it can cause a drop in blood pressure. Other effects can lead to decreased aldosterone secretion and Anti Diuretic Hormone (ADH) secretion that can lower blood pressure by reducing water and salt retention and water absorption (Guerrero L et al., 2012).

Vitamin $\mathrm{C}$ is a powerful antioxidant that reduces oxidative stress and enhances endothelial function through the production of nitric oxide which has a vasodilator effect. Vitamin $\mathrm{C}$ increases the concentration of intracellular which is a cofactor tetrahydrobiopterin synthase endothelial nitric oxide resulting in the production and bioactivity of nitric oxide increases. If there is a decrease in nitric oxide levels in the body, it can disrupt the process of endothelial relaxation resulting in the occurrence of hypertension (Fernandes PRO et al., 2011).

AVERRHOA BILIMBI L also has a diuretic effect that can accelerate urine to reduce the workload of the heart. Diuretics have antihypertensive effects by increasing the release of water and sodium salts (Kurup \& Mini, 2016). Potassium maintains the electrolyte stability of the body through the sodiumpotassium pump, reduces the amount of water and salt in the body and loosens the blood vessels so that the amount of salt in the blood vessels enlarges; this condition helps blood pressure to normalise (Caetano, Fonseca, Fernandes, Regina, \& Pereira, 2017).

\section{CONCLUSIONS}

Extract water from AVERRHOA $B I L I M B I L$ effectively decreases blood pressure in hypertension patient

\section{REFERENCES}

Adrogué HJ, \& NE, M. (2007). Sodium and Potassium in the Pathogenesis of Hypertension. N Engl J Med, (356), 1966-78.

Agency for Health Research and Development. (2013). Basic Health Research (RISKESDAS) 2013. National Report 2013, 1-384. https://doi.org/1 December 2013

Caetano, C. P., Fonseca, M., Fernandes, C., Regina, E., \& Pereira, S. (2017). Neurotoxicity following the 
Ingestion of Bilimbi Fruit (Averrhoa bilimbi) in an End-Stage Renal Disease Patient on Hemodialysis, 643, 6-12. https://doi.org/10.1159/000454945

Fernandes PRO, FAS, L., VVL, B., MJC, C., IC, T., MSB, S., \& AC, S. (2011). Vitamin C Restores Blood Pressure and Vasodilator Response During Mental Stress In Obese Children. Sociedade Brasileira de Cardiologia.

Guerrero L, J, C., S, G.-V., L, A., G, P., \& B, M. (2012). Inhibition of Angiotensin-Converting Enzyme Activity by Flavonoids: StructureActivity Relationship Studies. PLoS ONE, 7 (11). https://doi.org/e49493. doi: 10.1371 / journal.pone.0049493

Hasim, N. B. (2014). STUDY ON BIOACTIVE COMPOUND DEGRADATION FROM BELIMBING MULTIPLE (AVERRHOA BILIMBI), (July). Kurup, S. B., \& Mini, S. (2016). ScienceDirect Averrhoa bilimbi fruits attenuate hyperglycemiamediated oxidative stress in streptozotocin-induced diabetic rats. Journal of Food and Drug Analysis, 25 (2), 360-368. https://doi.org/10.1016/j.jfda.2016. 06.007

Muhammadun. (2010). Living together Hypertension is the high blood smirk of the killer instantaneously. Yogyakarta: Divagress. Safitri R. (2015). The Influence of Starfruit Fruit Extract (Averrhoa
Bilimbi L) on Blood Systolic Pressure Sprague Dawley. Journal of Nutrition College, 4 (2), 541546.

Tashakori-sabzevar, F., Marjan, B., Imenshahidi, M., Daneshmandi, M., Fatehi, H., Entezari, Y., \& Ahmad, S. (2016). Evaluation of mechanism for antihypertensive and vasorelaxant effects of hexanic and hydroalcoholic extracts of celery seed in normotensive and hypertensive rats. Revista Brasileira de Farmacognosia, 26 (5), 619-626. https://doi.org/10.1016/j.bjp.2016. 05.012

Triyanto. (2014). Nursing Services for Patients with Hypertension in an integrated manner. Jakarta: Graha Ilmu. 